\title{
The crack propagating behavior of composite coatings prepared by PEO on aluminized steel during in situ tensile processing
}

\author{
Zhitong Chen ${ }^{\mathrm{a}, \mathrm{b}}$, Guang $\mathrm{Li}^{\mathrm{a}, *}$, Zhenqiang $\mathrm{Wu}^{\mathrm{a}, \mathrm{c}}$, Yuan Xia ${ }^{\mathrm{a}, *}$ \\ a Institute of Mechanics, Chinese Academy of Sciences, Beijing 100190, China \\ ${ }^{\mathrm{b}}$ Graduate University of Chinese Academy of Sciences, Beijing 100049, China \\ ${ }^{\mathrm{c}}$ Beijing Institute of Structure and Environment Engineering, Beijing 100076, China
}

\section{A R T I C L E I N F O}

\section{Article history:}

Received 8 August 2010

Received in revised form 12 October 2010

Accepted 12 October 2010

\section{Keywords:}

Plasma electrolytic oxidation

Composite coatings

In situ tensile test

Thickness ratio

Crack opening displacement

\begin{abstract}
A B S T R A C T
This paper investigates the in situ tensile cracks propagating behavior of composite coatings on the aluminized steel generated using the plasma electrolytic oxidation (PEO) technique. Cross-sectional micrographs and elemental compositions were investigated by scanning electron microscopy (SEM) equipped with energy dispersive spectroscopy (EDS). The composite coatings were shown to consist of $\mathrm{Fe}-\mathrm{Al}, \mathrm{Al}$ and $\mathrm{Al}_{2} \mathrm{O}_{3}$ layers. The cracks propagating behavior was observed in real-time in situ SEM tensile test. In tensile process, the cracks were temporarily stopped when cracks propagated from $\mathrm{Fe}-\mathrm{Al}$ layer to Al layer. The critical crack opening displacement $\delta_{\mathrm{c}}$ was introduced to quantitatively describe the resistance of the $\mathrm{Al}$ layer. There was a functional relation among the thickness ratio $t_{\mathrm{Al}} / t_{\mathrm{Al}_{2} \mathrm{O}_{3}}$, the $\delta_{\mathrm{c}}$ of composite coatings and tensile cracks' spacing. The $\delta_{\mathrm{c}}$ increased with the increasing of the thickness ratio $\left(t_{\mathrm{Al}_{1}} / t_{\mathrm{Al}_{2} \mathrm{O}_{3}}\right)$. The high $\delta_{\mathrm{c}}$ value means high fracture resistance. Therefore, a control of the thickness ratio $t_{\mathrm{Al}} / t_{\mathrm{Al}_{2} \mathrm{O}_{3}}$ was concerned as a key to improve the toughness and strength of the aluminized steel.
\end{abstract}

(c) 2010 Elsevier B.V. All rights reserved.

\section{Introduction}

As an environment friendly technology, plasma electrolytic oxidation (PEO) coatings are gaining more and more attention [1]. Combining electrochemistry oxidation with plasma discharge in electrolyte, PEO technique produces ceramic coatings with excellent properties such as high hardness [2-4], wear resistance [5-7], corrosion resistance [8-11] and thermal protection [12]. However, it is difficult to prepare dense ceramic coating directly on steel by PEO. One of the best methods for preparing ceramic coating on steel was composite surface technologies, such as thermal spray/PEO, plasma sputtering/PEO, hot-dipped aluminum/PEO [13-15]. Additionally, ceramic composite coatings with high adhesion prepared by PEO process on the aluminized steel had been reported [16].

The ceramic coatings exhibits wear and corrosion resistance properties, but it is brittle to endanger the tensile property of steel [17]. Xin et al. [18,19] showed that the PEO ceramic coatings would reduce the tensile strength of aluminum substrate, the ratio of elongation and necking in the tensile test, whereas the elastic modulus of material was increased. The research on ceramic coating failure under mechanical load provides the basis of predicting the break strength of ceramic coating.

\footnotetext{
* Corresponding author.

E-mail addresses: lghit@imech.ac.cn (G. Li), xia@imech.ac.cn (Y. Xia).
}

For the above investigations, the tensile behavior of PEO ceramic coatings was studied from macro-scale. It was necessary to study the micro crack propagating behavior of ceramic composite coatings, but there was lack of related works. Cracks of a thin $\mathrm{Al}_{2} \mathrm{O}_{3}$ film on a ductile $\mathrm{Al}-5 \% \mathrm{Mg}$ substrate were investigated by a simplified 2D finite element analysis in the tensile testing [20]. It showed that the normal stress distribution in coating segments with various widths and the shear stress distribution along coating-substrate interfaces. The cracks of PEO coating on aluminum alloy were studied using a four-point bending test [21]. It showed that micro bevel cracks in the coating induce the onset and extension of interfacial crack. In this paper, crack propagation of composite ceramic coatings was studied by in situ tensile experimental method. A crack opening displacement (COD) theory was introduced by Wells [22]. It pointed out that the plastic zone existed around crack tip leading to the crack tip surface open. The opening volume was named as crack opening displacement $(\delta)$. When $\delta$ reached a critical value of materials $\left(\delta_{\mathrm{c}}\right)$, cracks started to penetrate. In this paper, authors intended to use the $\delta_{\mathrm{c}}$ method to analyze and evaluate the cracks.

This work focuses on investigating the crack propagating behavior and the failure mechanism of PEO composite ceramic coatings using a real-time in situ tensile test. Effects of the thickness ratio $t_{\mathrm{Al}} / t_{\mathrm{Al}_{2} \mathrm{O}_{3}}$ on the tensile crack propagation behavior were considered. Furthermore, a crack propagating model was established in order to describe the crack propagating process. 


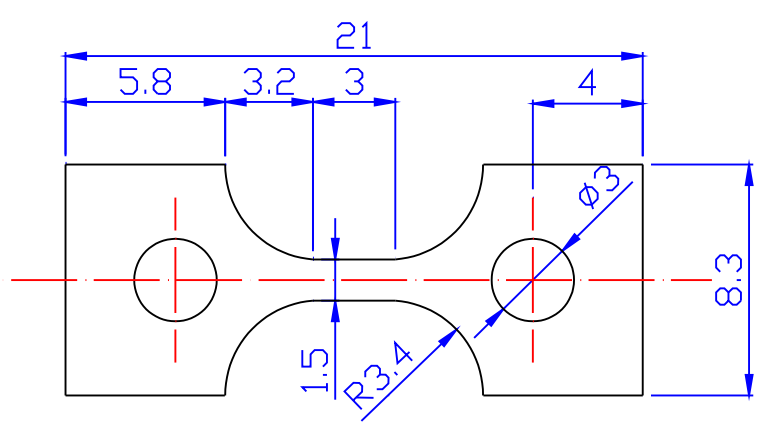

Fig. 1. Specimen size of in situ SEM tensile.

Table 1

Thickness ratios of composite coatings for in situ tensile test.

\begin{tabular}{llll}
\hline \multirow{2}{*}{ Coating type } & Layer & \\
\cline { 2 - 4 } & $\mathrm{Al}_{2} \mathrm{O}_{3}$ layer $(\mu \mathrm{m})$ & $\mathrm{Al}$ layer $(\mu \mathrm{m})$ & Ratio of $\mathrm{Al} / \mathrm{Al}_{2} \mathrm{O}_{3}$ \\
\hline $\mathrm{C} 1(45 \mathrm{~min})$ & 15 & 17 & 1.13 \\
$\mathrm{C} 2(75 \mathrm{~min})$ & 30 & 10 & 0.33 \\
$\mathrm{C} 3(90 \mathrm{~min})$ & 41 & 2 & 0.05 \\
\hline
\end{tabular}

\section{Experimental}

Rectangular samples $(25 \mathrm{~mm} \times 20 \mathrm{~mm})$ of Q235 steel (0.14-0.22\% Cu, 0.30-0.65\% Mn, 0.3\% Si, 0.045\% P, Fe balance) hot dipping the industrial pure aluminum (99.7\% purity) were used as the substrate. The thickness of the resulting Al layer was 30-50 $\mu \mathrm{m}$, with Fe-Al layer about $60 \mu \mathrm{m}$ thick. Prior to PEO treatment, the substrates were mechanically polished to achieve a surface finish of $\mathrm{Ra} \approx 0.1 \mu \mathrm{m}$, ultrasonically cleaned in ethanol for $5 \mathrm{~min}$, and dried.

Composite ceramic coatings were formed with a $5 \mathrm{~kW}$ plasma electrolytic oxidation unit comprising an AC power supply, a bipolar pulse unit and a stainless steel container equipped with stirring and cooling systems. The samples and container walls were used as the anode and cathode, respectively. An electrolyte prepared from an alkali-silicate solution $\left(16 \mathrm{~g} / 1 \mathrm{Na}_{2} \mathrm{SiO}_{3}\right.$ and $\left.2 \mathrm{~g} / \mathrm{l} \mathrm{NaOH}\right)$ in distilled water was cooled below $30^{\circ} \mathrm{C}$ during the entire treatment procedure. Three kinds of reference coating samples for the experiments were produced using average current at a density of $4 \mathrm{~A} / \mathrm{dm}^{2}$ for $45 \mathrm{~min}, 75 \mathrm{~min}$ and $90 \mathrm{~min}$, respectively. For samples, a bipolar pulse current was applied at frequency of $50 \mathrm{~Hz}$ and the ratio of anodic current to cathodic current was 1 . Specimen size of in situ SEM tensile was shown in Fig. 1. The tensile region was $3 \mathrm{~mm} \times 2 \mathrm{~mm} \times 1.5 \mathrm{~mm}$. To observe each layer of composite coatings, observing scope was polished and slightly corroded by $4 \%$ nitric acid alcohol for $10 \mathrm{~s}$.
Table 2

Testing results of in situ tensile samples.

\begin{tabular}{|c|c|c|c|c|c|c|}
\hline \multirow[t]{3}{*}{ Coating type } & \multicolumn{6}{|c|}{ Load and stress } \\
\hline & \multicolumn{3}{|c|}{ Tensile load $P(\mathrm{~N})$} & \multicolumn{3}{|c|}{ Tensile stress $\sigma(\mathrm{MPa})$} \\
\hline & $P_{\mathrm{S}}$ & $P_{\mathrm{b}}$ & $P_{\mathrm{c}}$ & $\sigma_{\mathrm{s}}$ & $\sigma_{\mathrm{b}}$ & $\sigma_{\mathrm{c}}$ \\
\hline Aluminized steel & 633 & 790 & 401 & 226 & 282 & 143 \\
\hline $\mathrm{C} 1\left(t_{\mathrm{Al}} / t_{\mathrm{Al}_{2} \mathrm{O}_{3}}=1.13\right)$ & 643 & 706 & 580 & 229 & 252 & 207 \\
\hline $\mathrm{C} 2\left(t_{\mathrm{Al}} / t_{\mathrm{Al}_{2} \mathrm{O}_{3}}=0.33\right)$ & 622 & 700 & 577 & 222 & 250 & 206 \\
\hline $\mathrm{C} 3\left(t_{\mathrm{Al}} / t_{\mathrm{Al}_{2} \mathrm{O}_{3}}=0.05\right)$ & 599 & 729 & 604 & 213 & 260 & 215 \\
\hline
\end{tabular}
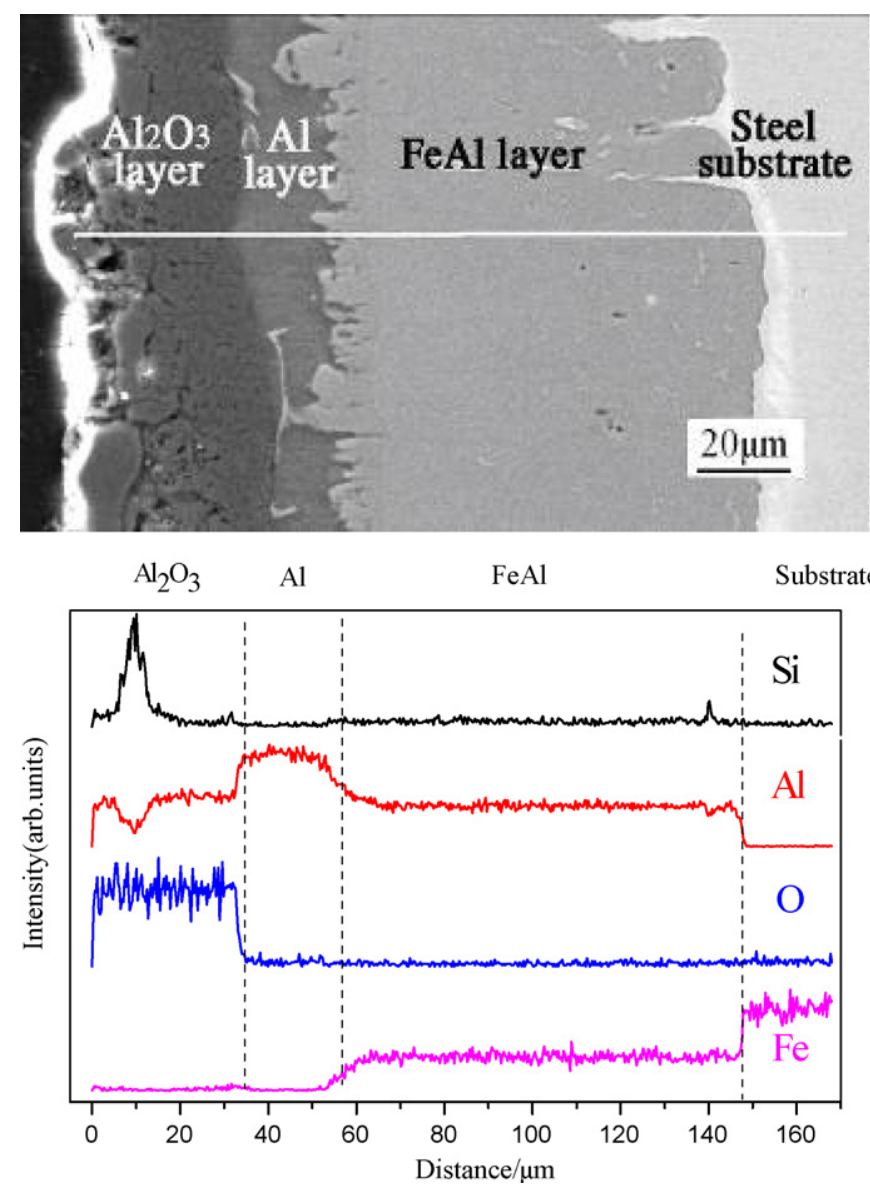

Fig. 3. Element distribution along the coating profile at $75 \mathrm{~min}$ (sample C2).
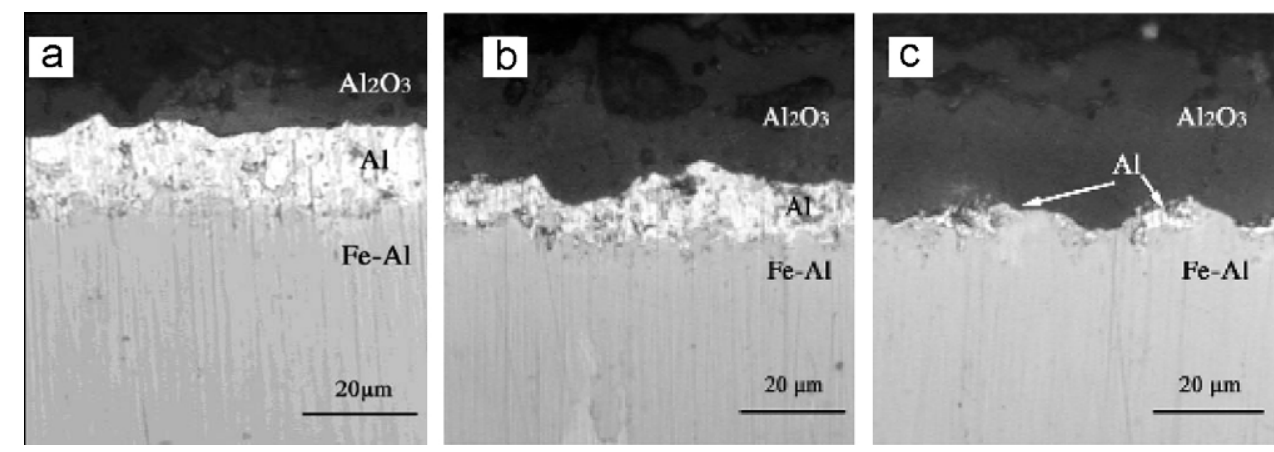

Fig. 2. Cross-section morphologies of samples (a) C1, $45 \mathrm{~min}$, (b) C2, $75 \mathrm{~min}$ and (c) C3, 90 min. 
Cross-sectional micrographs were observed using an XJP-6A metallographical microscope and the thickness of coatings was determined by microscope. Elemental compositions of coatings were investigated using a FEI Quanta 200 FEG scanning electron microscopy (SEM) with energy dispersive spectroscopy (EDS). For SEM and EDS test, thin carbon films were sprayed on the samples to provide a conductive surface. During in situ tensile process the surface morphologies of the coatings were observed by S-570 SEM operating at $20 \mathrm{kV}$.

\section{Results and discussion}

\subsection{Cross-sectional micrographs and element distribution}

The cross-sectional morphologies of composite coatings are shown in Fig. 2. Three kinds of samples were treated by PEO at $45 \mathrm{~min}, 75 \mathrm{~min}$ and $90 \mathrm{~min}$, respectively. These coatings are multilayer structures that comprise of three layers from substrate to

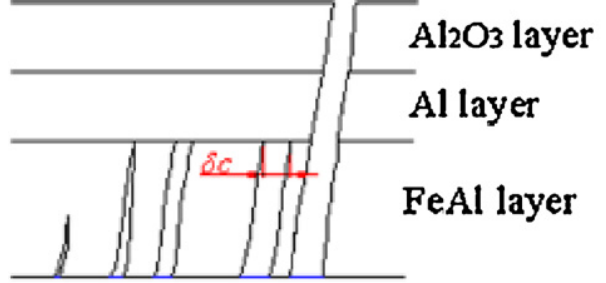

\section{Steel substrate}

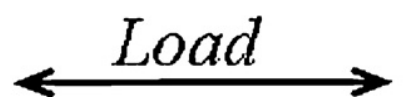

Fig. 7. The schematic diagram of crack propagating model. (For interpretation of the references to color in this figure legend, the reader is referred to the web version of the article).
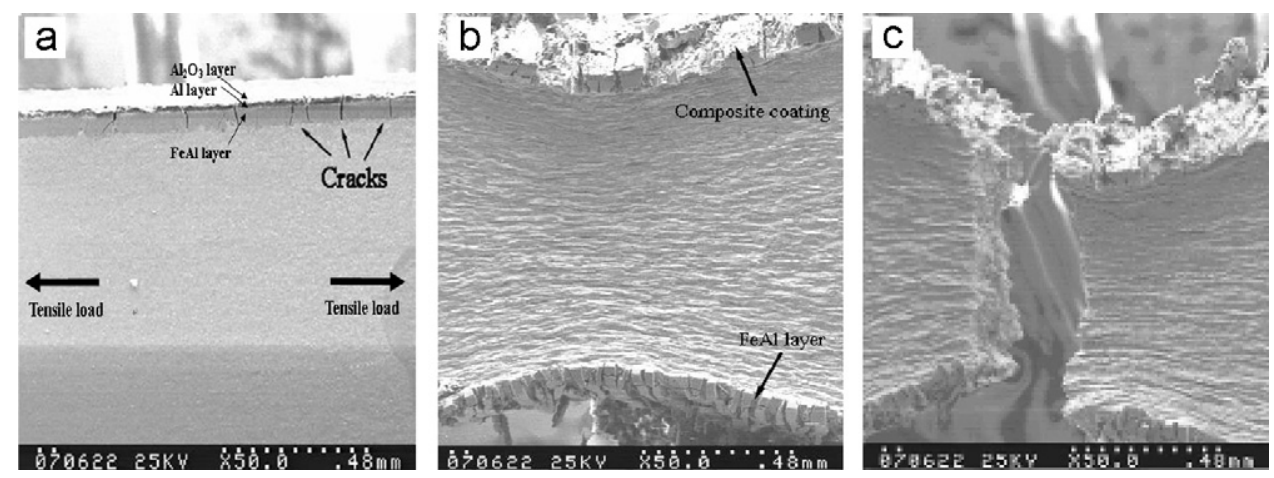

Fig. 4. In situ tensile test for crack initiation and fracture of ceramic coating.
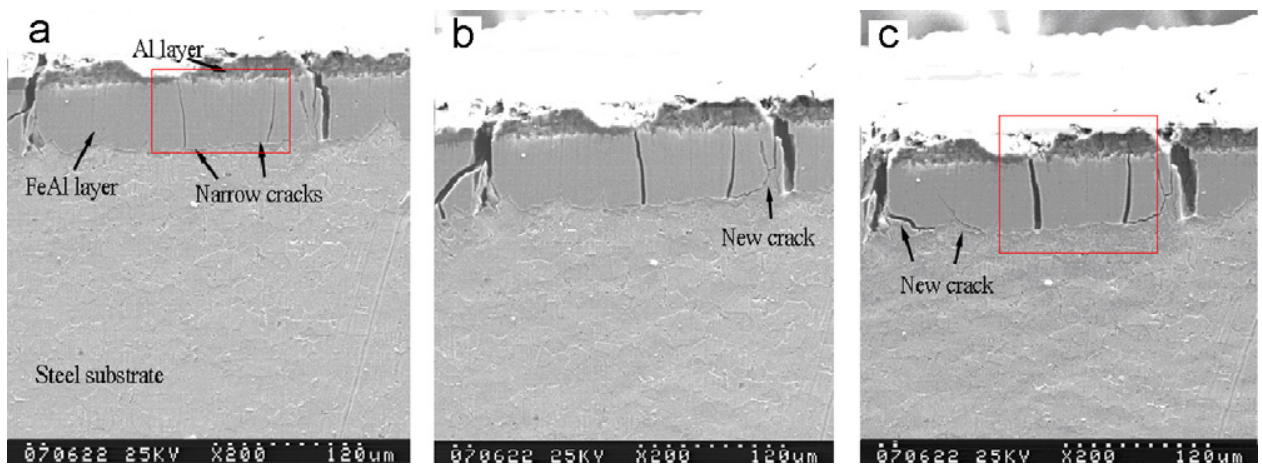

Fig. 5. Tensile cracks propagation when $t_{\mathrm{Al}} / t_{\mathrm{Al}_{2} \mathrm{O}_{3}}>1$.
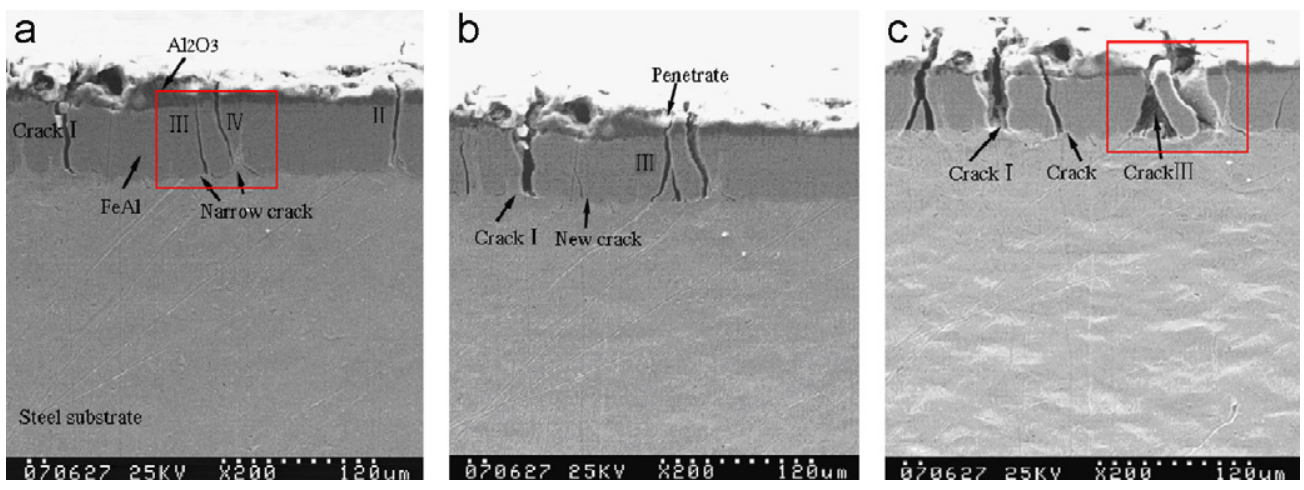

Fig. 6. Tensile cracks propagation when $t_{\mathrm{Al}} / t_{\mathrm{Al}_{2} \mathrm{O}_{3}}<0.05$. 

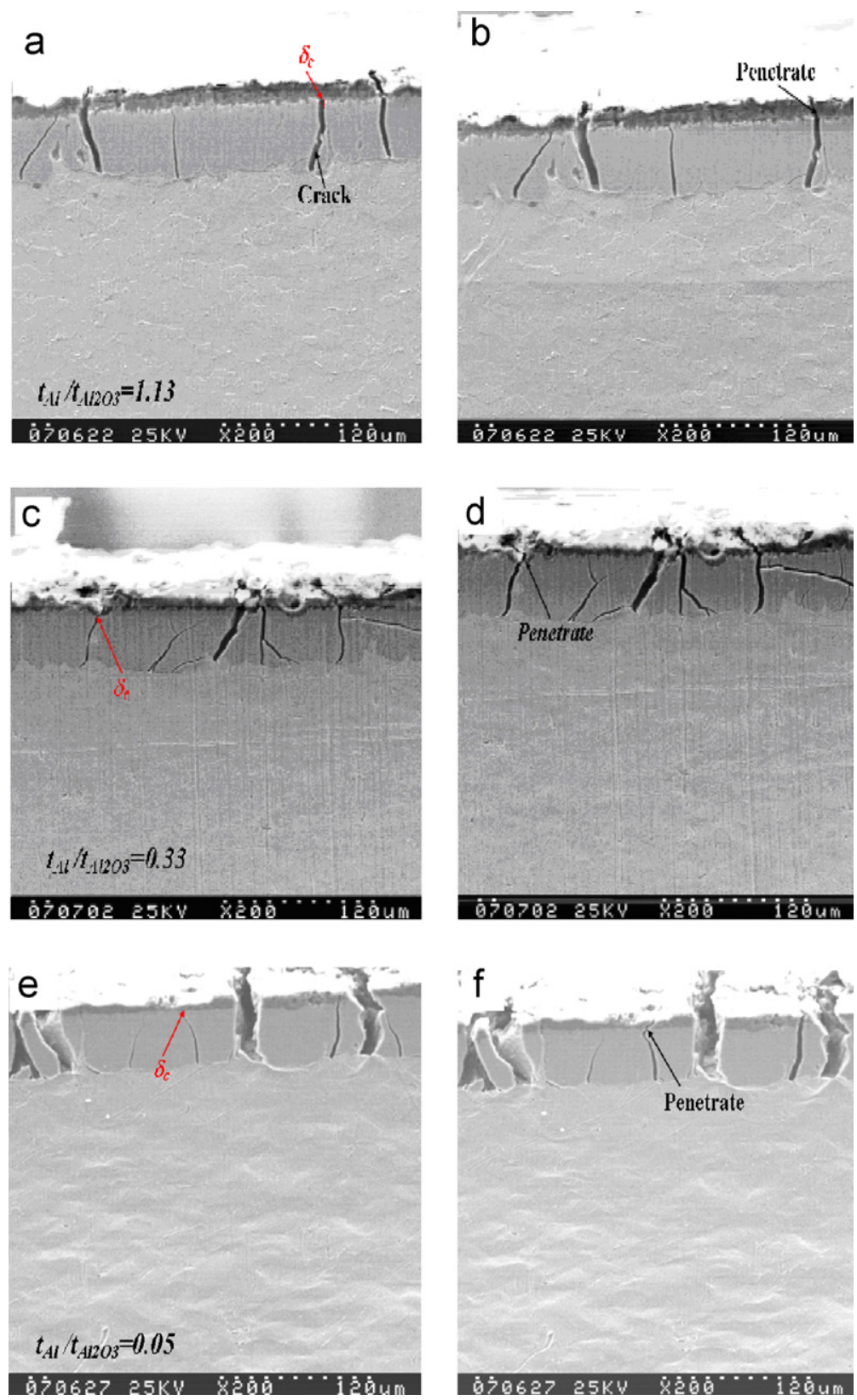

Fig. 8. The critical opening displacements of cracks in composite coatings. (a, b) C1, 45 min; (c, d) C2, 75 min and (e, f) C3, 90 min.

surface: Fe-Al layer, Al layer and $\mathrm{Al}_{2} \mathrm{O}_{3}$ layer (ceramic coating). Composite coatings with different thickness ratio $\left(t_{\left.\mathrm{Al} / t_{\mathrm{Al}_{2} \mathrm{O}_{3}}\right) \text { were }}\right.$ prepared, the thickness of the Fe-Al layer was kept constant. The average thickness and the thickness ratio of each layer of tensile sample (C1, C2 and C3) are shown in Table 1.

The Fe-Al layer was formed by the intermetallic reaction of Fe and $\mathrm{Al}$ elements and mutual diffusion during the hot-dip process. The ceramic coating at the surface is loose, while the ceramic coating near Al layer is relatively dense. Fig. 2(c) shows that most parts of Al layer have already been oxidized and some discrete $\mathrm{Al}$ particles exist near the $\mathrm{Al}_{2} \mathrm{O}_{3} / \mathrm{Fe}-\mathrm{Al}$ interface. The elemental distribution along the cross-section at $75 \mathrm{~min}$ is shown in Fig. $3 . \mathrm{Al}_{2} \mathrm{O}_{3}$ layer is composed of $\mathrm{Al}, \mathrm{Si}$, and $\mathrm{O}$. The $\mathrm{Fe}-\mathrm{Al}$ layer did not participate in the $\mathrm{PEO}$ process at that time because there was a thin Al layer between $\mathrm{Al}_{2} \mathrm{O}_{3}$ layer and $\mathrm{Fe}-\mathrm{Al}$ layer.

\subsection{Load and strength of in situ tensile test}

The results of the composite ceramic coatings in situ tension are shown in Table 2. $P_{\mathrm{s}}, P_{\mathrm{b}}$ and $P_{\mathrm{c}}$ corresponded to the tensile load of the yield strength $\sigma_{\mathrm{s}}$, the tensile strength $\sigma_{\mathrm{b}}$ and the fracture strength $\sigma_{\mathrm{c}}$, respectively.

The yield strength $\sigma_{\mathrm{s}}$ of PEO composite coatings is similar with aluminized steel without the PEO treatment. The fracture strength $\sigma_{\mathrm{c}}$ of PEO composite coatings is higher than aluminized steel without the PEO treatment, but yield strength $\sigma_{\mathrm{s}}$ is lower than aluminized steel without the PEO treatment. In PEO composite coatings, the yield strength $\sigma_{\mathrm{s}}$ of composite coatings increased with the thickness ratio, while the tensile strength and the fracture strength decreased. Composite ceramic coatings showed fracture character. The thickness ratio $t_{\mathrm{Al}_{1}} / t_{\mathrm{Al}_{2} \mathrm{O}_{3}}$ affected strength and tough- 
ness of composite ceramic coatings. It also affected the crack behavior of composite ceramic coatings.

\subsection{The crack initiation and fracture of ceramic composite coating}

The cracks distribution in ceramic coatings during in situ tension test was showed in Fig. 4 . When the tensile load reached $P_{\mathrm{s}}$, as shown in Fig. 4(a), the initial vertical cracks were found in the $\mathrm{Fe}-\mathrm{Al}$ layer and the cracks were all perpendicular to tensile load. The cracks initiation of aluminized steel without the PEO treatment was similar with PEO composite coatings. The space between vertical cracks in the Fe-Al layer was $150-160 \mu \mathrm{m}$.

Fig. 4(b) and (c) shows that composite coatings suffered from elastic deformation stage, yield stage and strengthening stage when the tensile load reached $\sigma_{\mathrm{b}}$ in the tensile test. Some local areas of specimen appeared obvious shrinkage. As shown in Fig. 4(c), the necking phenomenon was more and more obvious with the increase of the tensile load until the fracture happened (the tensile load reached $\sigma_{\mathrm{c}}$ ).

The initial vertical crack easily generated on the Fe-Al layer during the tensile test process. As load was increased, cracks in the Fe-Al layer propagated to the Al layer. However, these cracks' propagations were temporarily blocked by the Al layer. The width of crack was defined as the opening displacement $\delta$. The opening displacement $\delta$ increased as the load increased. When the opening displacement $\delta$ reached a critical value, cracks would penetrate the $\mathrm{Al}$ layer and the ceramic coating $\left(\mathrm{Al}_{2} \mathrm{O}_{3}\right.$ layer $)$ at the same time.

\subsection{The effect of thickness ratio $\left(t_{\mathrm{Al}} / \mathrm{t}_{\mathrm{Al}_{2} \mathrm{O}_{3}}\right)$ on crack propagation behavior}

\subsubsection{Tensile cracks propagation when $t_{\mathrm{Al}} / t_{\mathrm{Al}_{2} \mathrm{O}_{3}}>1$}

Fig. 5 showed the tensile behavior of cracks when $t_{\mathrm{Al}} / t_{\mathrm{Al}_{2} \mathrm{O}_{3}}>$ 1. As shown in Fig. 5(a), narrow cracks were mainly initiated in the interface of the Fe-Al layer/substrate. With the load increasing, shown in Fig. 5(b), cracks propagated to the interface of the Fe-Al layer/Al layer and the opening displacement $\delta$ of crack increased. Small horizontal cracks connecting two kinds of cracks appeared in the interface of the Fe-Al layer and the substrate. The horizontal cracks were the same direction with the tensile load. Furthermore, some horizontal new cracks appeared in the interface of the $\mathrm{Fe}-\mathrm{Al}$ layer/steel substrate as the load increased, shown in Fig. 5(c), which extend along interface.

\subsubsection{Tensile cracks propagation when $t_{\mathrm{Al}^{\prime}} / t_{\mathrm{Al}_{2} \mathrm{O}_{3}}<0.05$}

When the thickness ratio decreased to $t_{\mathrm{Al}} / t_{\mathrm{Al}_{2} \mathrm{O}_{3}}<0.05$, i.e., the Al layer was mostly transformed into the $\mathrm{Al}_{2} \mathrm{O}_{3}$ layer. New cracks' propagation behaviors were found as follows: two initial propagation cracks (III, IV) between wide cracks (I, II) were selected as the object of investigation shown in Fig. 6.

In Fig. 6(b) the crack-III was bifurcated. Although the opening displacement of crack-III was small enough, cracks had penetrated $\mathrm{Al}$ layer and $\mathrm{Al}_{2} \mathrm{O}_{3}$ layer. Other new cracks were also found in the Fe-Al layer between crack-I and crack-III. Those new cracks initiated from the Fe-Al layer/substrate interface and easily propagated to coating surface. Comparing with thickness ratio $t_{\mathrm{Al}} / t_{\mathrm{Al}_{2} \mathrm{O}_{3}}>1$, it was clear that the horizontal propagation cracks in the interface of $\mathrm{Fe}-\mathrm{Al}$ layer/substrate were not found during tensile processes.

\subsection{The critical value of cracks opening displacement}

The crack propagating model was established based on above investigations, which was shown in Fig. 7. The critical opening displacement $\delta_{\mathrm{c}}$ was also labeled by red in Fig. 7. Steel substrate and

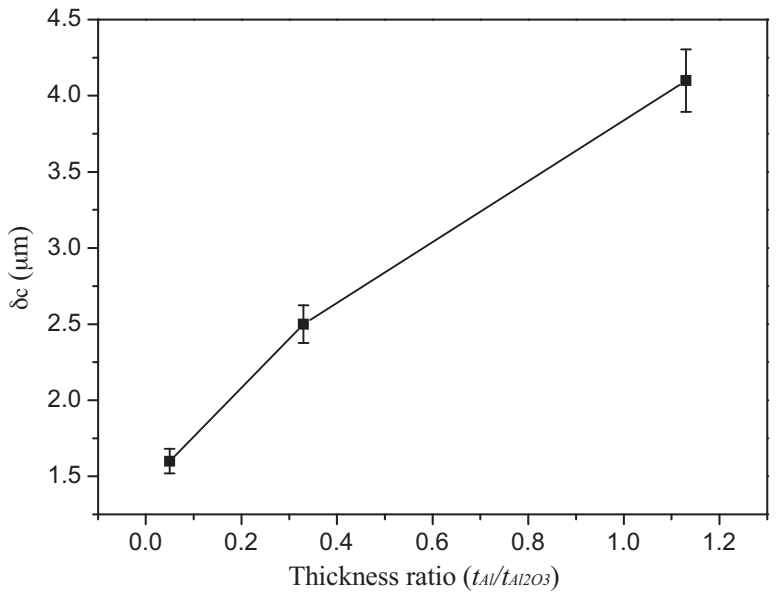

Fig. 9. The $\delta_{\mathrm{c}}$ of composite ceramic coatings with different thickness ratio.

Al layer both belong to plastic materials, whereas Fe-Al layer and the $\mathrm{Al}_{2} \mathrm{O}_{3}$ layer belong to brittle materials. Hence, when the cracks initiating from the $\mathrm{Fe}-\mathrm{Al}$ layer/substrate interface propagated to $\mathrm{Al}$ layer and steel substrate, the cracks' propagations were temporarily blocked by the Al layer and steel substrate. When the opening displacement $\delta$ reached a critical value, cracks would penetrate the $\mathrm{Al}$ layer and $\mathrm{Al}_{2} \mathrm{O}_{3}$ layer at the same time. The critical opening displacement $\delta_{\mathrm{c}}$ represented the fracture resistance of composite coatings. The higher the critical opening displacement $\delta_{\mathrm{c}}$ was, the better the toughness of composite coatings was.

The propagating behavior of vertical cracks was affected by the thickness ratio $\left(t_{\mathrm{Al}} / t_{\mathrm{Al}_{2} \mathrm{O}_{3}}\right)$. Fig. 8 showed that the different thickness ratio $\left(t_{\mathrm{Al}} / t_{\mathrm{Al}_{2} \mathrm{O}_{3}}\right)$ affected the cracks critical opening displacement $\delta_{c}$.

The crack critical opening displacement $\delta_{\mathrm{c}}$ of composite coatings with different thickness ratio $\left(t_{\mathrm{Al}} / t_{\mathrm{Al}_{2} \mathrm{O}_{3}}\right)$ is shown in Fig. 9. It can be seen that the thickness ratio $\left(t_{\mathrm{Al}} / t_{\mathrm{Al}_{2} \mathrm{O}_{3}}\right)$ increased with the $\delta_{\mathrm{c}}$ increasing. The thickness ratio $t_{\mathrm{Al}} / t_{\mathrm{Al}_{2} \mathrm{O}_{3}}>1$ means that the $\mathrm{Al}$ layer is much thicker. Al layer belongs to plastic materials, which blocked the propagation of cracks in the tensile process. There was almost no Al layer when the thickness ratio $t_{\mathrm{Al}} / t_{\mathrm{Al}_{2} \mathrm{O}_{3}}<0.05$. Without block effect of $\mathrm{Al}$ layer, the cracks initiated on the $\mathrm{Fe}-\mathrm{Al}$ layer/substrate interface and easily penetrated $\mathrm{Al}$ layer and $\mathrm{Al}_{2} \mathrm{O}_{3}$ layer. The cracks propagation of the thickness ratio $t_{\mathrm{Al}} / t_{\mathrm{Al}_{2} \mathrm{O}_{3}}>1$ is more difficult than the thickness ratio $t_{\mathrm{Al}} / t_{\mathrm{Al}_{2} \mathrm{O}_{3}}<0.05$. The value of $\delta_{\mathrm{c}}$ depends on the thickness of Al layer. This work provides a method to evaluate the cracks failure of composite ceramic coatings.

\section{Conclusions}

Composite coatings on the aluminized steel were prepared by the plasma electrolytic oxidation (PEO) technique, which comprised of $\mathrm{Fe}-\mathrm{Al}$ layer, $\mathrm{Al}$ layer and $\mathrm{Al}_{2} \mathrm{O}_{3}$ layer. Ceramic coating is mainly composed of $\mathrm{Al}, \mathrm{Si}$ and $\mathrm{O}$. The different thickness ratio $t_{\mathrm{Al}} / t_{\mathrm{Al}_{2} \mathrm{O}_{3}}$ would affect strength and toughness of substrate. The vertical cracks initiated on the $\mathrm{Fe}-\mathrm{Al}$ layer/substrate interface and the cracks' propagations were temporarily blocked by the Al layer in tensile process. The plastic Al layer played the role to delay cracks propagating to ceramic coating. The critical crack opening displacement $\delta_{\mathrm{c}}$ was introduced to describe quantitatively the resistance of the Al layer and evaluate the fracture behavior of composite coatings. The crack critical opening displacement $\delta_{\mathrm{c}}$ increased with the thickness ratio $\left(t_{\mathrm{Al}} / t_{\mathrm{Al}_{2} \mathrm{O}_{3}}\right)$ increasing. Finally, the crack propagating model was established. 


\section{Acknowledgements}

The authors would like to thank the financial support of the National Nature Science Foundation of China (Nos. 10832011, 10772179).

\section{References}

[1] A.L. Yerokhin, X. Nie, A. Leyland, A. Matthews, Surf. Coat. Technol. 122 (1999) 73-93.

[2] X. Nie, A. Leyland, H.W. Song, A.L. Yerokhin, S.J. Dowey, A. Matthews, Surf. Coat. Technol. 119 (1999) 1055-1060.

[3] L.R. Krishna, K.R.C. Somaraju, G. Sundararajan, Surf. Coat. Technol. 163 (2003) 484-490.

[4] W.B. Xue, C. Wang, Z.W. Deng, R.Y. Chen, Y.L. Li, T.H. Zhang, J. Phys. Condens. Matter 14 (44) (2002) 10947-10952.

[5] X. Nie, E.I. Meletis, J.C. Jiang, A. Leyland, A.L. Yerokhin, A. Matthews, Surf. Coat. Technol. 149 (2-3) (2002) 245-251.

[6] R. Arrabal, E. Matykina, P. Skeldon, G.E. Thompson, Appl. Surf. Sci. 255 (2009) 5071-5078.

[7] P. Bala Srinivasan, C. Blawert, W. Dietzel, Mater. Sci. Eng. A 494 (2008) 401-406.
[8] H.P. Duan, K.Q. Du, C.W. Yan, F.H. Wang, Electrochim. Acta 51 (14) (2006) 2898-2908.

[9] R.C. Barik, J.A. Wharton, R.J.K. Wood, K.R. Stokes, R.L. Jones, Surf. Coat. Technol. $199(2-3)(2005) 158-167$

[10] F. Monfort, A. Berkani, E. Matykina, P. Skeldon, G.E. Thompson, H. Habazaki, K. Shimizu, Corros. Sci. 49 (2007) 672-693.

[11] Y. Ma, X. Nie, D.O. Northwood, H. Hu, Thin Solid Films 494(1-2)(2006)296-301.

[12] J.A. Curran, T.W. Clyne, Surf. Coat. Technol. 199 (2-3) (2005) 177-183.

[13] Z.Q. Wu, Y. Xia, G. Li, F.T. Xu, Acta Metall. Sin. 44 (2008) 119-124.

[14] W.C. Gu, D.J. Shen, Y.L. Wang, G.L. Chen, W.R. Feng, G.L. Zhang, S.H. Fan, C.Z. Liu, S.Z. Yang, Appl. Surf. Sci. 252 (2006) 2927-2932.

[15] Z.Q. Wu, Y. Xia, C.J. Zhang, G. Li, J. Inorg. Mater. 22 (2007) 534-538.

[16] Z.Q. Wu, Y. Xia, G. Li, F.T. Xu, Appl. Surf. Sci. 253 (2007) 8398-8403.

[17] W.B. Xue, C. Wang, Y.L. Li, Z.W. Deng, R.Y. Chen, T.H. Zhang, Mater. Lett. 56 (2002) 737-743.

[18] S.G. Xin, L.X. Song, R.G. Zhao, X.F. Hu, Surf. Coat. Technol. 199 (2005) 184188.

[19] T.B. Wei, F.Y. Yan, W.M. Liu, J. Tian, Trans. Nonferr. Met. Soc. China 14 (2004) 1162-1168.

[20] C.J. Xie, W. Tong, Acta Mater. 53 (2005) 477-485.

[21] Y.J. Guan, Y. Xia, F.T. Xu, Surf. Coat. Technol. 202 (2008) 4204-4209.

[22] A.A. Wells, Application of fracture mechanics at and beyond general yielding, Br. Weld. J. 11 (1963) 563-570. 